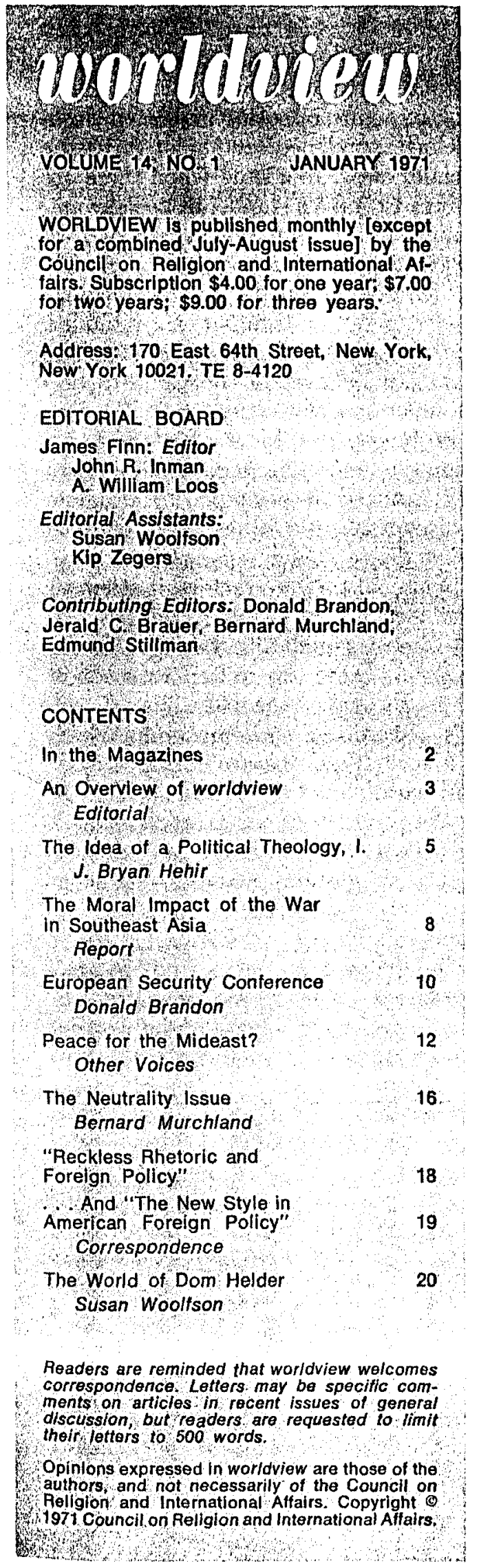

\section{AN OVERVIEW OF worldview}

What is worldview? What should it be? Phrased in different ways, the first question is put to us with growing frequency. The result, partly, of some modest promotion on our part and therefore a modest gain in our readership. As our readers have leamed, it is impossible to discern the character of worldview from a single issue, and difficult to tell what it is from only two or three.

Some of the rcasons for this difficulty are easy to state. When worldview was begum, slightly over ten years ago, it joined the varied family of American journals of opinion that are devoted to political and cultural affairs. It immediately shared many of their problems, e.g., finding the right responsive audience; coping with problems which, in their importance and intensity, are unprecedented in U.S. history; and the immediate, constant problem of meeting the rising costs of printing and publishing. But there are also self-imposed limitations that are unique to worldview, restrictions that largely determine the character of the journal.

First, the journal focuses on international affairs (as do a number of journals) and attempts to place the discussion within an ethical framework (as do fewer journals) and to relate the ethical judgments to specifically religious traditions (as does no other journal we know). Clearly, not every article can attempt to do all of these things. Some articles will be primarily descriptive and analytical, focusing on some limited political aspects of an issue. Other articles will make explicit the connections between the political judgment and the informing ethic. Still others will explore the relation of ethical systems, insights and judgments to a religious tradition.

The intention, the hope, the goal, the continuing task is to provide within the pages of worldview the context within which each article-complete in itself, incomplete within the total intent of the joumal-can be fully evaluated. That task was not an easy one when the journal was launched by its first editor, William Clancy. It is even more difficult now. The first issue of January, 1958, stated editorially that "worldview is edited from the viewpoint of the West's perennial tradition, which is decply, essentially rooted in the values of the Judco-Christian, classical humanist view of man and society. 'This joumal will not 'preach', but it will insist -sometimes explicitly, more often implicitly-that this tradition is relevant to, even normative for, the survival of any world worth saving."

Almost immediately a number of difficulties with this 
formulation became evident. In the second issue, Arthur A. Cohen wrote of "The Jewish-Christian Contradiction," saying "It is essential to maintain, against the superficiality of contemporary JudeoChristian fraternity and brotherhood, the fact that Judaism and Christianity divide profoundly. This division is not repaired by the impermanent cement of sociology or the religious ignorance of contemporary man. . . this difference is not without consequences for the conduct of world affairs."

If Mr. Cohen stressed difficulties rclated to one part of that formulation, what shali we say of those related to the "classical humanist view of man and society"? Where, indeed, are the best spokesman for that view, which is everywhere in retreat in the West? For what we are witnessing now, it should be clear, is the crumbling of the last redoubts in which that view was firmly upheld, Wo are witnessing as well the conflict of views, of creeds that would replace that view.

Behind many of our current disorders and debates is the pereninial religious question, "What is man that thon art mindful of him?" Some journals disdain or reject that question; others deal with it only implicitly and erratically, unaware, in fact, that they are dealing with it at all. worldview asserts that it is the question, that unless one responds to it one camot adequately cope with other contemporary questions. worldeiew does not pretend that a sound, compelling response is easy. In fact, it offers itself as one forum in which serious responses to the question can he stated and debated.

Which brings us to our second point of difference with most journals of opinion in this country. With possible exceptions--but which they are, we can't now recall-the leading journals of opinion in this country represent particular schools of thought:" When one mentions The New Republic, The Nation, New Leader, or National Review one knows the different directions they take. And so too with America, Commonweal, Christianity Today, Christian Century, Christianity and Crisis. And with Commentary and the New York Review of Books.

We read these journals, wher and if we do, to be informed on some particular issue, but also to have confinmed our own prejudices, attitudes, incompletely developed positions. At their best they help us to think better in the direction we have already decided.

worldview has taken upon itself a different and, in some ways, more difficult task. It advances no single point of view, is committed to no partisan position, advances no single platform or program as the solution, Instead, it brings together different partisan viewpoints, opposing and often clashing, as the Correspondence section in this issue makes especially clear. In a time when there are strong pressures to "take a stand," to be relevant, engaged, committed, ours is not a sure path to brushfire popularity, worldview quite consciously risks the charge of being called-quite erroneously we believe-a cop out, a trimmer, a bystander. But worldview takes this risk because at a time of confrontation it believes in the value of dialogue; at a time of apocalyptic assertion it fosters a tentative, probing search for the better course; at a time when the limitations of reason are being unreasonably asserted it attempts to promote reasonable discourse; at a time when political action is being discredited by some of its practitioners and many of their detractors, it attempts to uphold the necessity and value of politics.

Well-that almost sounds like taking a stand, having a position, being committed to a set of values. And in the terms we have just stated, world tiew is committed and engaged. Which leads us to the second question we initially asked: "What should worldview be?" We have ideas of our own, as the progress of the journal through the last dozen years should attest. But we welcome comments, suggestions, positive and negative criticisms, letters, and articles. The character of worldeiew is established, we feel, but it is not fixed. Especially to our new readers who have not previously received our offer, we would like to extend the invitation to participate in the venture which is worldview. J.F.

\section{NEXT MONTH}

"Polities is ubout men first (and last), about their hopes, visions, realities, sins, failures, possibilities, power, and evils. When we fail to prepare our youth and the rest of us for such as man is, when others see us so failing in political insight, are we doing anything more than leading innocent sheep to slaughter? . . Chitles Reich's new citizen is characterized most viridly as one who is totuly imocent-and therefore totally a-political. It is no wonder that Arstotle suid of such a man that he was either a beast or a god, no wonder that Christran politicat thought places stch a creature either beforc the Fall or after this life..."

- James V. Schall in "The 'Blackening \& Blucing' of America" 